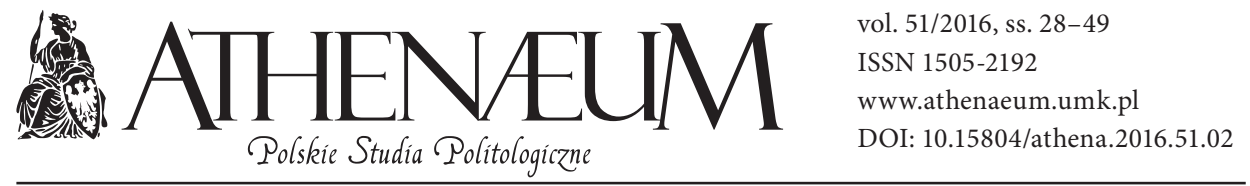

\title{
ROLA I MIEJSCE SOCJOLOGII POLITYKI W SYSTEMIE WIEDZY POLITOLOGICZNEJ
}

\author{
THE PLACE AND THE ROLE OF POLITICAL SOCIOLOGY \\ IN THE POLITICAL SCIENCE KNOWLEDGE SYSTEM
}

Jakub Potulski*

\begin{abstract}
ABSTRAKT
O odrębności poszczególnych dyscyplin w ramach nauki decyduje ich specyficzny przedmiot i metody badawcze. Nierzadko spotyka się jednak dyscypliny, których przedmiot badań pokrywa się bądź też jest trudny do rozgraniczenia. Nauka o ludzkim społeczeństwie, jego powstaniu, rozwoju, przekształceniach łączy w sobie wiele względnie samodzielnych, ale także powiązanych ze sobą gałęzi wiedzy. Zjawiska ze sfery polityki z uwagi na swoją wielowymiarowość wykraczają poza ścisłe granice jednej tylko dziedziny. Dlatego też we współczesnym obrazie rozwoju nauk o polityce obserwuje się odchodzenie od tradycyjnych wąskodyscyplinarnych ujęć na rzecz tzw. ujęć integracyjnych, interdyscyplinarnych. Jednym z takich ujęć jest socjologia polityki, która ma "łączyć” badania politologiczne i socjologiczne. Z uwagi na wieloznaczność podmiotową i przedmiotową, a także nieostre granice pomiędzy naukami społecznymi, socjologia polityki należy do dyscyplin niepoddających się łatwym definicjom i uogólnieniom. $\mathrm{W}$ artykule autor podjął rozważania dotyczące
\end{abstract}

The article concerns identity dilemmas of political sociology and its role in political research. Political institutions and process are intimately related to sociological phenomena. The relationship between sociology and political science has long traditions. Classic sociologists - Max Weber, Karl Marx - were also creators of political science. It is difficult to determine boundaries between social and political phenomena and boundaries between study of society and study of politics. The problem of boundaries is particularly intense in the case of subarea like political sociology, which exists within or between the two disciplines which have formed it: political science and sociology. The primary goal of political sociology is to analyze power and politics and how they operate in social life. Traditionally, political sociology has been concerned with the relations between society and the state, and traditional political sociology takes the modern nation-state as the center of political activity. The main problem of political sociology is lack of consensus on the subject of study and different interpretations of

* Uniwersytet Gdański, Instytut Politologii. 
tożsamości badawczej socjologii polityki oraz nad jej rolą i miejscem w systemie wiedzy o polityce.

Słowa kluczowe: socjologia, politologia, socjologia polityki, analiza systemowa the objects of study by sociologist and political scientist. In this article, the author tries to answer the question, what is the role of political sociology in the knowledge structure concerning politics. Studies that cross the boundaries between sociology and political science help to enhance our understanding of both politics and society.

Keywords: sociology, political science, political sociology, system theory

Społeczeństwo ludzkie stanowi całość, w której trudno oddzielić od siebie poszczególne sfery aktywności. Nauka o ludzkim społeczeństwie, jego powstaniu, rozwoju, przekształceniach, łączy w sobie wiele względnie samodzielnych, ale także powiązanych ze sobą gałęzi wiedzy. Jest to problem tego, jak np. analizując rzeczywistość społeczną, oddzielić od siebie to, co polityczne, od tego co ekonomiczne, i od tego co społeczne? Taka dystynkcja jest przecież fundamentem ukształtowania się ekonomii, socjologii i politologii jako nauk dysponujących własnym, ściśle zdefiniowanym przedmiotem badań, odrębnym od innych dziedzin. Zjawiska społeczne wykraczają jednak poza granice tylko jednej dyscypliny. Dla celów heurystycznych i analitycznych wyodrębnia się różne dziedziny nauk społecznych (filozofia, historia, prawo, ekonomia, socjologia, psychologia czy też politologia), ale przedmiot poznania tych nauk jest jeden: człowiek i wytwory jego działalności. Należy przy tym pamiętać, iż na obecnym etapie rozwoju humanistyki mamy do czynienia z jednej strony ze specjalizacją i wyodrębnianiem się nowych obszarów badawczych, aspirujących do tego, aby stać się samodzielną dyscypliną, z drugiej zaś strony świadomość faktu, że postępująca segementyzacja nauk społecznych oraz zbyt rygorystyczne przestrzeganie rozgraniczeń przedmiotowych - z konieczności zmiennych i zamazanych - nie sprzyja ciekawości zgłębiania natury rzeczy, powoduje, że najbardziej cenione są ujęcia wykraczające poza granice tylko jednej dziedziny wiedzy. Według Immanuela Wallersteina otwieranie się dyscyplin naukowych „każdego z nas osobna i wszystkich razem” nie jest „jedną z możliwych opcji”, ale strategią minimum dla intelektualnego przetrwania nauk społecznych i zapewnienia istotności ustaleń (Wallerstein, 2004, s. 203).

Jednym z kontrowersyjnych i „nieostrych” przedmiotów refleksji naukowej jest sfera „polityczności”. Trudno jest sformułować precyzyjną i jednoznaczną 
definicję polityki, gdyż wielostronny i bezpośredni sposób, w jaki polityka przejawia się w życiu codziennym ludzi, nasuwać musi różnorodne odpowiedzi. Polityka jest specyficznym zjawiskiem społecznym, związanym z grupowaniem się ludzi i ich działaniami. Istnieje zgoda co do tego, że polityka to sfera działalności społecznej powstała w wyniku interakcji między ludźmi. Jej pojawienie się w życiu człowieka związane jest ze społecznym charakterem egzystencji ludzkiej. Różnorodność i wielość sposobów przejawiania się polityki w życiu ludzkim powoduje, że refleksji nad sferą polityki towarzyszy duże zróżnicowanie stanowisk badawczych. Kompleksowość i wielowymiarowość polityki jako dziedziny życia społecznego powoduje, że sfera polityki jest obiektem zainteresowania ze strony wielu dyscyplin nauk społecznych, z których każda rozpatruje ją, kierując się różnorodnymi kryteriami przyjętymi przez daną dziedzinę wiedzy. Każda z tych dyscyplin bada określony element zjawisk i procesów politycznych, każda próbuje formułować określone prawidłowości związane ze zjawiskami i procesami politycznymi; każda z nich bada też zagadnienia metodami właściwymi dla danej dyscypliny. Ponadto podejmowane są próby stworzenia osobnej dziedziny naukowej - politologii, która byłaby podstawą do zbudowania jednolitej uniwersalnej teorii polityki.

Istotnym problemem przy próbie zrozumienia specyfiki politologii był jednak zawsze fakt, iż różnorodność i wielość sposobów przejawiania się polityki w życiu ludzkim powodowała, że refleksji nad tą sferą życia zbiorowego towarzyszyło duże zróżnicowanie stanowisk badawczych. Trudność całościowego opisania specyfiki sfery polityczności związana jest z problemem ujęcia całej jej złożoności w jednej zunifikowanej teorii. Badania politologiczne określa się często jako interdyscyplinarne. W przypadku politologii interdyscyplinarność oznacza otwartość na dorobek badawczy i metodologiczny innych dyscyplin nauk społecznych, zajmujących się problematyką polityczną, a nawet „okołopolityczną” oraz gotowość do dzielenia się z tymi dyscyplinami własnymi doświadczeniami, teoriami wyjaśniającymi oraz instrumentarium badawczym. Politologia jest stosunkowo młodą dyscypliną badawczą. Jej pełna autonomia i instytucjonalizacja nastąpiła dopiero po drugiej wojnie światowej. Ale tematyka „politologiczna” traktowana była jako przedmiot dociekań naukowych dużo wcześniej, a najwcześniejsze ślady refleksji nad polityką sięgają świata antycznego. Wyodrębnienie się politologii jako samodzielnej (autonomicznej) i zinstytucjonalizowanej dyscypliny nie oznaczało zaprzestania prowadzenia badań nad polityką w ramach innych („wyjściowych”) dyscyplin nauki. W dalszym ciągu w obszarze filozofii, historii, socjologii, nauk prawnych, ekonomii czy też psychologii prowadzi się badania 
specjalistyczne nad określonymi aspektami rzeczywistości politycznej. Dyscypliny naukowe, z których wyodrębniła się politologia, posiadają od niej bogatsze doświadczenie w prowadzeniu badań i mają dłuższą tradycję metodologiczną. Dlatego też politolodzy nie tylko sięgają po ustalenia badawcze przyjęte na gruncie innych nauk, ale również po ich techniki i metody prowadzenia badań (Modrzejewski, 2011).

Aby politologia była relewantną dyscypliną badawczą cieszącą się uznaniem w świecie akademickim, trzeba podejmować refleksję nad przedmiotem badań, dbać o spójną i jasną siatkę pojęciową, wypracować metodologię możliwie adekwatną do danego przedmiotu badań i celów poznawczych, wskazywać na pola badawcze o szczególnym walorze dla współczesnej politologii, a także podkreślać samodzielny charakter politologii, wskazując na jej granice dyscyplinarne. Te granice zawsze będą „porowate", ale bez refleksji dotyczącej roli i miejsca politologii wśród innych nauk społecznych trudno wyobrazić sobie przyszłość dyscypliny. Jednym z problemów współczesnych badań politologicznych jest „polityzacja” naszego życia, która powoduje, że coraz więcej fenomenów życia społecznego zostaje „upolityczniona”. Powoduje to, że coraz większa ilość badaczy podejmuje tematy „polityczne”, wkraczając na teren badań politologicznych, prowadząc swoje badania pod wygodnymi i pojemnymi szyldami "psychologii polityki”, „antropologii polityki”, „socjologii polityki”, czy też „europeistyki”, co prowadzi do rozproszenia badań nad sferą polityczności i zachowaniami politycznymi.

Szczególnie trudnym wyzwaniem jest wskazanie na specyfikę socjologii polityki i ukazanie jej miejsca w systemie wiedzy socjologicznej i politologicznej. Definicja przedmiotu socjologii polityki nie doczekała się we współczesnej nauce rozwiązania zadowalającego wszystkich i przez wszystkich akceptowanego (por. Wiatr, 1999). Celem artykułu jest analiza typowych sposobów definiowania przedmiotu badań socjologii polityki, a także próba wskazania na jej miejsce w systemie wiedzy o polityce. Według autora artykułu socjologia polityki $\mathrm{w}$ „gmachu” wiedzy o polityce stanowi nie tyle osobną subdyscyplinę badawczą, ile raczej specyficzne „podejście” do badania rzeczywistości politycznej.

Podejmując rozważania dotyczące roli i miejsca socjologii polityki w systemie wiedzy o polityce, należy podkreślić, że naukowa wiedza i badania dotyczące sfery polityczności stopniowo krystalizują się jako osobna dziedzina wiedzy od połowy dwudziestego wieku i proces ten nie wydaje się w pełni zakończony. Ogromna różnorodność pól badawczych, ich złożoność i wielość powiązań między nimi, stwarza poważne wyzwania w zakresie budowania scalających ujęć teoretycznych, takich jak politologia. Szczególnie dużą trudność sprawia rozdzielenie tego, co społeczne 
(socjologia), od tego, co polityczne (politologia). Tak, jak „wiedza o społeczeństwie” (socjologia) stopniowo wyodrębniała się z filozofii, aby za sprawą Augusta Comte’a uzyskać swoją autonomię, tak politologia stopniowo wyodrębniała się z filozofii, a następnie socjologii, aby w drugiej połowie dwudziestego wieku uzyskać swoją autonomię akademicko-badawczą. Jednakże linia dzieląca socjologię od politologii jest trudna do jednoznacznego wyznaczenia, a politolodzy i socjolodzy „rywalizują” ze sobą, uzasadniając albo negując sens istnienia odrębnej sfery badań dotyczącej zjawisk i procesów politycznych. W debatach z politologami na temat kompetencji badawczych i zakresu badań socjologowie często utrzymują, że niezależne badanie państwa i innych instytucji politycznych nie ma sensu teoretycznego. Jest to nawiązanie do tradycji Talcotta Parsonsa i jego przekonania, że badanie polityki nie może być traktowane w kategoriach wyspecjalizowanego schematu pojęciowego, dlatego że aspekt polityczny systemu społecznego jest punktem skupienia dla integracji wszelkich analitycznie wyodrębnionych elementów tego systemu, a nie szczególnie wyróżnioną klasą tych elementów. Problem odróżnienia tego, co społeczne, od tego, co polityczne, i rywalizacji badaczy o uznanie własnej sfery badań za jedyną uprawnioną, która powinna podejmować się analiz sfery polityczności, jest dziś szczególnie widoczny. Jak zwracał uwagę Anthony Giddens, „procesy strukturacji wiążą się wzajemnymi relacjami między znaczeniami, normami i władzą. Te trzy pojęcia są równoważne analitycznie jako najbardziej podstawowe terminy nauk społecznych i pozostają w logicznym związku zarówno z pojęciem działania intencjonalnego, jak i struktury: każdy ład poznawczy i moralny jest zarazem systemem władzy, wiążąc się z horyzontem prawomocności" (Giddens, 2001, s. 226). W praktyce badawczej oznacza to, że każda forma konceptualizacji życia społecznego obejmuje potrzebę uwzględniania politycznych aspektów relacji jednostka - społeczeństwo. Dlatego też bez wiedzy politologicznej czy też - inaczej mówiąc - wiedzy o „politycznych” zachowaniach człowieka niemożliwe jest budowanie całościowej teorii społecznej.

„Polityzacja” naszego życia społecznego, a także rosnąca świadomość, że zagadnienia polityki pełnią fundamentalną rolę $\mathrm{w}$ budowaniu wiedzy socjologicznej, co przejawia się w przekonaniu, że nie można budować teorii socjologicznej bez rozważania problemów, które są ze swej natury polityczne (Kidd, Legge i Harari, 2010), powoduje, że socjologowie przypisują coraz większą rolę badaniom nad sferą polityki ${ }^{1}$, a przy okazji, broniąc swojej instytucjonalnej

${ }^{1}$ Warto zwrócić uwagę na fakt, że socjologia polityki stanowi obecnie jeden z najważniejszych obszarów zainteresowań socjologii. Około $20 \%$ artykułów publikowanych w takich czasopismach, 
pozycji w sformalizowanym, akademickim systemie nauk (a w tym dostępu do środków finansowych przeznaczanych na rozwój nauki), zawłaszczają badania nad sferą polityki, często nie mając do tego dostatecznych kompetencji, co może wynikać z nieznajomości dorobku politologii w zakresie budowania wiedzy o polityce. Instytucjonalne i ambicjonalne konflikty na linii socjologia - politologia utrudniają rozwój nauki i podjęcie zaawansowanych badań dotyczących natury funkcjonowania systemów politycznych oraz specyfiki politycznych zachowań jednostek. Badania nad sferą polityki są dziś niezwykle „modne”, ich prowadzenie często pozwala na uzyskiwanie środków finansowych, co powoduje, iż sfera polityczności staje się obszarem, który budzi zainteresowanie przedstawicieli różnorodnych dyscyplin, którzy dość arbitralnie czują się upoważnieni do podejmowania analiz sfery polityki.

Mimo że trudno wyobrazić sobie jakąkolwiek debatę czy też teorię socjologiczną, która nie odwoływałaby się do zjawisk, które ze swej natury są „polityczne”, można przyjąć uproszczone założenie, że podstawową przestrzeń badań, w której stykają się, a niekiedy rywalizują politolodzy i socjolodzy, można określić jako „socjologię polityki”. Pojawia się zatem pytanie, czym jest socjologia polityki i jaka jest jej rola w strukturze wiedzy politologicznej oraz socjologicznej. Socjologia polityki nigdy nie była polem badawczym, które łatwo można by odróżnić od innych dyscyplin podejmujących zagadnienia ze sfery polityki. O odrębności poszczególnych dyscyplin w ramach nauki decyduje ich specyficzny przedmiot i metody badawcze. Część badaczy zwraca uwagę, że trudno jest wskazać na taki wyodrębniony przedmiot badań socjologii polityki, który wyraźnie odróżniałby się od przedmiotu badań politologii, co więcej, nie istnieje nauka o polityce, która nie byłaby obecnie jednocześnie socjologią polityki (por. Lecomte 2005). Jest to dość kontrowersyjne stanowisko, gdyż rodzi się pytanie, czy socjolog, który w swoich pracach badawczych musi uwzględnić kompleks zjawisk związanych ze sferą polityki, automatycznie staje się politologiem. Czy działa to też w drugą stronę: każdy politolog musi mieć wiedzę o świecie społecznym, a więc automatycznie staje się socjologiem?

Wielowymiarowość i złożoność przedmiotu badań socjologii polityki powoduje, że powstaje problem, aby w jednoznaczny sposób ją zdefiniować i odróżnić od socjologii z jednej strony i politologii z drugiej. Socjologii polityki trudno

jak „American Journal of Sociology”, czy też „American Sociology Review”, jest poświęcona właśnie problematyce zjawisk politycznych; por. The Handbook of political sociology, (eds) T. Janoski, R. Alford, A. Hicks, M. Schwartz, Cambridge 2005, s.1. 
jest zachować tożsamość przedmiotowo-metodologiczną, ponieważ badania dystrybucji władz, procesów kształtowania się postaw politycznych, podejmowania decyzji politycznych czy też zachowań zbiorowych (ruchy społeczne, partie polityczne) krzyżują się z dziedzinami przedmiotowymi różnych subdyscyplin politologicznych oraz innymi subdyscyplinami samej socjologii. Dyskusje dotyczące tożsamości i specyfiki socjologii polityki stanowią stały element tej dyscypliny. Kiedy po drugiej wojnie światowej w USA zaczęły pojawiać się coraz liczniejsze prace, których przedmiot badań zaliczano do socjologii polityki, wielu badaczy próbowało odpowiedzieć na pytanie, czym jest socjologia polityki. Maurice Duverger w swojej wpływowej pracy Sociologie de la politique opublikowanej w 1966 r. pisał, iż politologia (political science) i socjologia polityki (political sociology) to synonimy i zajmują się tymi samymi problemami badawczymi. Giovanni Sartori w artykule From sociology of politics to political sociology z 1969 r. starał się przeprowadzić dystynkcję pomiędzy socjologią polityczną (sociology of politics) i socjologią polityki (political sociology). Dla Sartoriego socjologia polityczna stanowiła jedną z subdyscyplin ukształtowanych w ramach socjologii; charakteryzuje ją redukcja interpretacji polityki tylko do kategorii „socjologicznych”, a więc wyjaśnień w kategoriach „niepolitycznych”. Socjologia polityki była zaś dla włoskiego uczonego specyficzną dyscypliną badań, którą cechuje wielość i różnorodność stosowanych wyjaśnień. Socjologia polityki analizuje procesy polityczne, wykorzystując własną specyficzną terminologię, w kategoriach władzy, jej społecznej dystrybucji i jej efektów, odrzucając jednocześnie rozróżnienie na to, co społeczne, i na to, co polityczne (Sartori, 1969). Natomiast Manvir Olsen, starając się ukazać, czym różni się socjologia polityki od pozostałych działów socjologii, zwracał uwagę, że: 1. Podstawowym pojęciem powinna być kategoria socjopolitycznej organizacji społeczeństwa. To pojęcie kieruje uwagę na analizę procesów i struktur, poprzez które decyzje polityczne są podejmowane i wprowadzane w życie oraz następuje społeczny rozdział władzy. 2. Podstawową jednostką analizy powinno być państwo narodowe lub też któryś z jego komponentów, takich jak np. klasa rządząca czy też masowe ruchy polityczne. Socjologia polityki wyróżnia się tym, iż pomimo tego, że państwo narodowe stanowi dominującą formę organizacji politycznej we współczesnym świecie, żaden z pozostałych działów socjologii nie traktuje go jako podstawowej jednostki analiz. 3. Podstawowym analizowanym działaniem powinno być sprawowanie socjopolitycznej władzy. Ten typ aktywności może być opisywany w rozmaity sposób - dominacja, kontrola, wpływ, autorytet - ale zawsze oddziałuje silnie na kolektywne decyzje i aktywność. 4. Podstawowym 
obszarem zainteresowania powinny być relacje pomiędzy systemem politycznym a resztą społeczeństwa (Olsen, 1981).

Większość badaczy zajmujących się współcześnie socjologią polityki akceptuje szeroką definicję zaproponowaną przez amerykańskiego socjologa Anthonyego Oruma, że socjologia polityki kieruje swoją uwagę na społeczne uwarunkowania polityki, czyli na to, jak polityka jest kształtowana i jak wpływa na inne zjawiska społeczne. Zamiast traktowania pola polityki i aktorów politycznych jako niezależnych od innych sfer życia społecznego, socjologia polityki traktuje pole polityki jako ściśle związane ze wszystkimi pozostałymi instytucjami społecznymi (Orum, 1983). Czyli w najbardziej ogólnym sensie socjologia polityki koncentrowałaby się na relacjach pomiędzy społeczeństwem a polityką. Orum podkreślał, że specyfiką socjologii jest szerokie „panoramiczne” spojrzenie na sferę polityki i poszukiwanie związków pomiędzy polityką a pozostałymi instytucjami społecznymi. Takie podejście badawcze wywodzi się z założenia, że instytucje polityczne są zakorzenione w pozostałych instytucjach społecznych i w różnorodny sposób od nich uzależnione. Założenie to stało się jednym $z$ elementów konstytuujących tradycję badawczą socjologii polityki. Problemem jest jednak duże zróżnicowanie w określaniu pół badawczych dla socjologii polityki. Zasadniczo, biorąc pod uwagę szeroki zakres definicji Oruma, można założyć, że socjologowie polityki będą się interesowali władzą jako fenomenem, który przenika niemal każdą relację społeczną, łącząc ją z socjologiczną koncepcją polityki jako aktywności społecznej człowieka występującej w wielu instytucjach społecznych. W praktyce badawczej oznaczało to koncentrację zainteresowań badawczych na poziomie państwa narodowego. Jednostką analizy było wewnętrznie spójne „nowoczesne społeczeństwo” zorganizowane wokół państwa narodowego.

Jest to typowe, „klasyczne” ujęcie obszaru badań socjologii polityki, niemniej jednak pozostawiające wątpliwości co do specyficznego dla niej przedmiotu badań oraz znaczenia dla budowania wiedzy o zjawiskach politycznych. Duże trudności w określeniu, czym jest, lub też czym nie jest socjologia polityki, wynikają m.in. z odmiennej interpretacji tej dyscypliny przez socjologów i politologów. Problemem jest to, że socjologowie i politolodzy w odrębny sposób podchodzą do zagadnień związanych z polem badawczym socjologii polityki i odmiennie postrzegają to, co powinno być przedmiotem analizy. W przypadku socjologów dużą rolę w ukształtowaniu się rozumienia tego, czym jest socjologia polityki, odgrywa tradycja marksistowsko-weberowska i przekonanie, że stosunki polityczne to stosunki wynikające $z$ walki o władzę i sprawowanie 
władzy. Bardzo charakterystyczne dla socjologów jest przekonanie, że wszystkie aspekty życia społecznego bazują na zjawiskach związanych z władzą, a zrozumienie fenomenu władzy jest kluczem do zrozumienia tego, jak funkcjonuje społeczeństwo. W socjologii przyjmuje się, iż władza przenika niemal każdą relację społeczną - w szczególności występuje w grupach pierwotnych, takich jak rodzina, w grupach sformalizowanych, takich jak różnorodne organizacje społeczne i polityczne, wreszcie w państwie. Bardzo charakterystyczne są słowa Piotra Sztompki, który w podręczniku do socjologii pisał, że „na jednym biegunie w największej makroskali władza jest centralnym aspektem politycznych stosunków międzynarodowych, a także relacji gospodarczych między państwami czy korporacjami międzynarodowymi. Na drugim biegunie w skali mikro realizuje się w najprostszych międzyludzkich kontaktach czy interakcjach. Występuje jako władza państwa nad obywatelami, przełożonych nad podwładnymi, nauczycieli nad uczniami czy rodziców nad dziećmi” (Sztompka, 2002, s.369).

W takim szerokim rozumieniu zjawiska władzy, określanej raczej jako fenomen społeczny, jest ona traktowana jako klucz do zrozumienia polityki i zachowań politycznych człowieka. Stąd też bierze się socjologiczne przekonanie, że wszelkie analizy sfery polityki za punkt wyjścia czynią zrozumienie, czym jest władza jako zjawisko społeczne. W siatce pojęciowej kluczową rolę odgrywa zatem pojęcie władzy rozumianej najczęściej jako możliwość narzucania swojej woli i zmuszenia innych do działania zgodnego z naszą wolą oraz pojęcie polityki rozumianej najczęściej jako rywalizacja o władzę i podział władzy pomiędzy grupami oraz jednostkami. Przy czym polityka, zgodnie z konfliktową tradycją marksistowsko-weberowską, postrzegana jest jako przestrzeń konfliktu i dominacji. Dlatego też w literaturze przedmiotu można się spotkać z twierdzeniem, że podstawową siatkę terminologiczną socjologii polityki tworzą takie terminy, jak: władza, państwo, dominacja/hegemonia i rywalizacja (por. Neuman, 2010). W socjologicznym ujęciu przedmiotu badań socjologii polityki dominuje zatem redukcjonistyczna wizja sfery polityczności, a także tendencja do utożsamiania polityki z zagadnieniami władzy. Takie ujęcie powoduje, że socjologowie mają tendencję do utożsamiania sfery polityczności z „polityką”, a więc obserwowalnymi zachowaniami podmiotów polityki (jednostek, wyborców, decydentów politycznych, przywódców, partii politycznych, państw itp.), które rywalizują ze sobą o władzę w ramach instytucji politycznych, a zwłaszcza państwa narodowego.

Dla „socjologicznej” interpretacji pola zainteresowań socjologii polityki szczególnie istotny jest wpływ Maxa Webera. To przede wszystkim tradycja weberowska przyczyniła się do utożsamienia socjologii polityki z socjologią 
władzy. Weber uważał, że polityka jest atrybutem każdego społeczeństwa i każdej rzeczywistości społecznej, w której istnieje „władza”, a więc najogólniej mówiąc - stosunki nadrzędności i podrzędności. Ujmował on politykę poprzez pryzmat władzy, panowania i przemocy, gdyż uważał, iż władza jest podstawowym instrumentem kształtowania społeczeństwa, regulowania problemów, realizacji celów i dążeń ponadindywidualnych. W klasycznej definicji Webera władza oznaczała „szansę przeprowadzenia swej woli, także wbrew oporowi, w ramach pewnego stosunku społecznego, bez względu na to, na czym ta szansa polega" (Weber, 2002), natomiast polityka to „dążenie do udziału we władzy lub do wywierania wpływu na podział władzy, czy to między państwami, czy też w obrębie państwa między grupami ludzi (Weber, 2004). Dlatego też dla socjologii bardzo charakterystyczne jest pojmowanie socjologii polityki jako swoistego rodzaju „socjologii władzy”, czyli „subdyscypliny” socjologicznej zajmującej się analizami zjawiska władzy we wszelkich jej formach i postaciach, w jakich przejawia się ona w życiu społecznym.

Z tradycji socjologii weberowskiej pochodzi próba, tak charakterystyczna dla socjologów, utożsamienia socjologii polityki z analizami sfery władzy. $\mathrm{W}$ anglosaskich podręcznikach z zakresu socjologii polityki widać to bardzo wyraźnie, chociażby w definiowaniu roli socjologii polityki w ramach badań socjologicznych. W tym ujęciu zwraca się uwagę, że nowoczesna socjologia polityki w swoich badaniach i analizach koncentruje się na problematyce władzy i społecznym kontekście jej zdobywania i wykonywania. Przyjmując, iż władza jest fenomenem społecznym, występującym na wszystkich poziomach życia społecznego (w rodzinach, organizacjach, w związkach zawodowych, w instytucjach religijnych), podkreśla się, że socjologia polityki zajmuje się analizą władzy (Bottomore, 1993). Socjologia polityki jest analizą zjawiska władzy oraz relacji zachodzących pomiędzy społeczeństwem a sferą polityki (Neuman, 2005). W tym ujęciu przyjmuje się, iż wszelkie fenomeny/zjawiska życia społecznego bazują na władzy, stąd też wszystkie aspekty socjologicznych studiów dotyczących władzy stanowią socjologię polityki (Kidd, Legge i Harari, 2010). Zjawisko władzy, wyrastające $z$ nierównorzędnych, niezrównoważonych i pozbawionych wzajemności, asymetrycznych relacji międzyludzkich, traktuje się jako rdzeń socjologii polityki (por. Taylor, 2010), utrzymując, iż jest ona jawną siłą, przenikającą całe życie społeczne człowieka. Władza to fundamentalny wymiar wszystkich ludzkich relacji, a także instytucji społecznych. Polityka jest natomiast procesem, w którym duże grupy społeczne zdobywają, sprawują, utrzymują i tracą władzę (Neuman, 2005). Socjologia polityki bada zjawiska 
władzy we wszystkich jej wymiarach, gdziekolwiek ona występuje, wykraczając czasem poza granice tradycyjnej socjologii (Neuman, 2005).

Utożsamienie władzy z polityką, a socjologii polityki z socjologią władzy jest kontrowersyjnym zabiegiem, gdyż prowadzi do tego, że nie trudno jest przeprowadzić dystynkcję pomiędzy władzą a polityką. Po pierwsze takie ujęcie jest bardzo bliskie wyobrażeniom potocznym, znajdującym swoje odbicie we wszystkich językach europejskich, w których „polityka” kojarzy się najczęściej z „działaniem” albo „władzą”, albo zgoła z „działaniami władzy”. Przy szerokim ujęciu pojęcia polityki i utożsamieniu sfery „polityczności” ze wszystkimi tymi sytuacjami społecznymi, w których mamy do czynienia z władzą/autorytetem/ dominacją, gubi się jednak sens tego, co „polityczne”, gdyż wszystko nie może być polityczne (por. Skarzyński, 2012). Nie wszystko jest polityką, co prawda trudno jest dokonać wyróżnienia tego, co polityczne, w ramach tego, co społeczne, ale nie można wszystkim elementom społecznym przypisywać cechy polityczności, bo gubi się wówczas sens analiz nad sferą polityki, a wiedza „o polityce” zamienia się w zlepek różnorodnych często niespójnych „podejśćc badawczych (Skarzyński, 2012). Problemem jest w tym wypadku fakt, iż nie można rozpatrywać tego, co polityczne, jedynie w kategoriach „władzy”, gdyż wówczas ginie z oczu istota i sens sfery „polityczności”. To, co polityczne, staje się tym, co społeczne i na odwrót. W tym wypadku zjawiska polityczne, przestają być odróżnialne od zjawisk społecznych, gdyż zanika uchwytna granica pomiędzy systemem politycznym a systemem społecznym.

Należy pamiętać, że sam Weber przeprowadził dystynkcję pomiędzy władzą a polityką. Niemiecki uczony przyjmował bardzo szeroką definicję polityki i starał się zrozumieć jej istotę przede wszystkim poprzez analizę zjawiska władzy i panowania. Jednocześnie uważał, że władza i panowanie same w sobie nie tworzą jeszcze polityki jako społecznego działania. Konstytutywnymi jej czynnikami stają się dopiero w szczególnych okolicznościach w sprzężeniu z czynnikiem terytorialnym, ze wspólnotą terytorialną, stając się instrumentem realizacji jej celów. Dlatego też socjologia polityki Webera była państwocentryczna, gdyż niemiecki uczony uważał, iż wspólnota polityczna, związek polityczny i państwo stanowią główne podmioty polityki i jej właściwe pole analiz. Weber starał się zatem wyznaczyć granicę pomiędzy tym, co polityczne, i tym, co społeczne. Jeżeli takiej granicy nie wyznaczymy, to badanie zjawisk „politycznych” traci sens jako odrębna dyscyplina naukowa. Socjologiczna/weberowska tradycja postrzegania socjologii polityki jako badania fenomenu władzy, przyjmując uproszczony model władza = polityka, nie jest $\mathrm{w}$ stanie $\mathrm{w}$ pełni wyjaśnić specyfiki 
sfery polityczności, a tym samym ma ograniczone możliwości heurystyczne. Świadomość takich ograniczeń mają socjologowie, którzy próbują wyjść poza ograniczenia związane z klasyczną tradycją marksistowsko-weberowską i rozszerzyć przedmiot zainteresowań socjologii polityki, rozciągając go tak, że prawie niemożliwe staje się rozróżnienie pomiędzy socjologią polityki a politologią. Tzw. new political sociology koncentruje się głównie na zjawiskach „kulturowych”, przyjmując, że podstawowe pojęcia, które stanowią rdzeń socjologii polityki, to: władza, ideologia i tożsamość. Przy czym podkreśla się, iż pojęcia te muszą zostać zdefiniowane na nowo i rozpatrywane w kontekście głębokich przemian cywilizacyjnych, co powoduje, iż współcześni socjologowie polityki podejmują się analiz społeczno-politycznych skutków globalizacji i rosnącej globalnej współzależności ludzkich społeczeństw, wychodząc poza tradycyjne dla socjologii polityki obszary badawcze, a jednocześnie zatracając sens tego, czym była/ jest socjologia polityki (por. Nash, 2008; Taylor, 2010).

Tradycja socjologiczna traktująca socjologię polityki jako „socjologię władzy”, czyli obszar badań zajmujących się fenomenem władzy rozumianym jako szerokie zjawisko społeczne, jest nie do końca funkcjonalna dla politologów ze względu na wątpliwości, jakie budzi utożsamienie władzy i polityki. Dlatego też politolodzy próbowali znaleźć inny, specyficznie politologiczny sposób rozumienia tego, czym jest socjologia polityki. W tradycji politologicznej pojmowanie przedmiotu badań socjologii polityki najczęściej odwołuje się do koncepcji Seymoura Lipseta badania „społecznych podstaw polityki”. W tym ujęciu jest to szczególne podejście do teorii polityki, akcentujące wyjątkowo wielkie znaczenie relacji, które istnieją między stosunkami zachodzącymi w dziedzinie władzy politycznej a strukturą i rozwojem społeczeństwa jako całości (Lipset, 1995). Seymour Lipset wraz z Reinhardem Bendixem starali się określić, czym jest socjologia polityki. Badacze ci uznali, że podobnie jak nauka o polityce socjologia polityki zajmuje się rozdziałem i wykonywaniem władzy w społeczeństwie. W odróżnieniu jednak od nauki o polityce, nie zajmuje się ona instytucjonalnymi warunkami podziału i wykonywania władzy, lecz traktuje je jako dane. Tak więc nauka o polityce wychodzi od państwa i bada, jak oddziałuje ono na społeczeństwo, podczas gdy socjologia polityki wychodzi od społeczeństwa i analizuje, jak wpływa ono na państwo, tj. na formalne instytucje służące podziałowi i wykonywaniu władzy (Bendix i Lipset, 1957). W tym sensie w ramach politologii postrzega się socjologię polityki jako badanie „społecznych podstaw polityki” czy też inaczej mówiąc - społecznego otoczenia systemu politycznego i wzajemnych relacji pomiędzy systemem politycznym a otaczającym go środowiskiem. Byłoby 
to zatem szukanie wpływu, jaki wywierają na zjawiska polityczne różnorodne, działające w społeczeństwie czynniki. Seymour Lipset analizował zależność sposobów głosowania (zachowania polityczne) od podstawowych rodzajów różnic grupowych (struktura społeczna) i szukał cech społecznych, które są skorelowane $\mathrm{z}$ frekwencją wyborczą.

Ujęcie socjologii polityki zaproponowane przez Lipseta jest jednak obarczone bardzo istotną wadą, czy też może raczej „grzechem pierworodnym”. Sam Lipset pisał, iż jednym z podstawowych problemów socjologii politycznej jest analiza warunków społecznych sprzyjających demokracji, i że socjologia polityki w swoich badaniach powinna koncentrować się na problemie postawionym jeszcze przez Tocquevilla: społecznych wymogów i konsekwencji demokracji (Lipset, 1995). Można przyjąć, iż badanie „społecznych podstaw polityki (demokracji)" to bardzo dobra, syntetyczna definicja socjologii polityki. Definicja, która w zasadzie rozstrzyga wątpliwości co do przedmiotu jej zainteresowania. Problemem w tym wypadku jest to, że „badanie społecznych podstaw polityki (demokracji)" obarczone jest założeniami o charakterze normatywnym i ideologicznym. Bezpośrednio po drugiej wojnie światowej, w latach pięćdziesiątych, działalność z zakresu socjologii polityki koncentrowała się przeważnie w Stanach Zjednoczonych. Amerykanie po zwycięstwie nad faszyzmem uważali się za światowego lidera demokracji i wolności. Wzrost gospodarczy i stabilność społeczna budowały atmosferę pewności siebie. Podstawowym pytaniem, które sobie stawiano w tym okresie, było to, dlaczego niektóre społeczeństwa stają się demokratycznymi, podczas gdy inne totalitarnymi, faszystowskimi lub komunistycznymi. Dlatego też podejmowana tematyka badawcza koncentrowała się wokół warunków umożliwiających rozwój procesów demokratyzacji. Podjęto się analizy ekonomicznych, społecznych i psychologicznych warunków koniecznych dla rozwoju politycznej demokracji.

Morris Janowitz pisał, że socjologia polityki ma łączyć analizę ekonomicznych, społecznych i psychologicznych warunków koniecznych dla rozwoju politycznej demokracji. Większość prac, które powstawały w tym okresie, przyjmowały ten punkt widzenia. Amerykańscy badacze szukali warunków społecznych wspierających rozwój demokratycznych instytucji politycznych. Wysunięto hipotezę, że demokracja może pojawić się, należycie funkcjonować oraz wypełniać swoje zadania tylko w społeczeństwie znajdującym się na określonym poziomie rozwoju, wynikającym z historycznego i społecznego kontekstu (por. Potulski, 2011). Jedną z najsłynniejszych prac tego nurtu była książka Gabriela Almonda The civic culture, stanowiąca studium porównawcze postaw politycznych i demokracji 
w pięciu krajach, ukazująca, w jaki sposób wiąże się ze sobą rozwój polityczny i kulturowo-społeczny. Szerokim echem odbiła się zwłaszcza hipoteza, zgodnie z którą kultura polityczna (indywidualne postawy wobec polityki) uczestników danego systemu politycznego ma decydujący wpływ na rozwój demokracji. Praca Almonda jest przykładem problemów związanych z badaniem „społecznych wymogów demokracji”. Krytycy Almonda zwrócili uwagę, iż punktem wyjścia dla swoich analiz uczynili oni anglosaski ideał polityczno-społeczny, wedle którego oceniali wszystkie pozostałe kultury świata.

Warto pamiętać, iż analiza „warunków społecznych sprzyjających demokracji” powstawała w specyficznym okresie i w dużym stopniu przygotowywana była na „zamówienie polityczne”. Tego typu badania, podobnie zresztą jak różnego rodzaju teorie modernizacji, były elementem amerykańskiej polityki w okresie zimnej wojny. Amerykańskie instytuty badawcze miały udowodnić „wyższość” amerykańskiego modelu społeczno-politycznego. Pomimo interesujących uogólnień teoretycznych badania amerykańskich socjologów polityki miały podłoże ideologiczne, a wiele ich tez (np. że rozwój gospodarczy jest równoznaczny z demokratyzacją) budzi dziś wątpliwości jako nie w pełni potwierdzone empirycznymi obserwacjami. Dlatego też badanie „społecznych podstaw polityki” jest obciążone ideologicznym „grzechem pierworodnym”. Dlatego też, pojmując socjologię polityki jako badanie „społecznych podstaw polityki”, trzeba bardzo ostrożnie podchodzić do wyboru tematów badawczych i pamiętać o ograniczeniach związanych $\mathrm{z}$ takim podejściem do badania sfery polityczności. W tym sensie tradycja Lipseta, podobnie jak i tradycja weberowska, ma pewne istotne ograniczenia, o których politolodzy powinni pamiętać. Warto przy tym zauważyć, że współcześni badacze często bezkrytycznie odwołują się do tradycji Lipseta, nie pamiętając o ideologicznych „przedzałożeniach” poszukiwania „społecznych podstaw demokracji”. Między innymi dlatego można w literaturze przedmiotu spotkać się ze stwierdzeniami, że socjologia polityki koncentruje się na relacjach władzy pomiędzy państwem a społeczeństwem obywatelskim (por. Faulks, 2000). Skłonność do bezrefleksyjnego powtarzania popularnych i modnych haseł powoduje, że przedmiotem badań, i to zarówno politologicznych, jak i socjologicznych, czyni się społeczeństwo obywatelskie. Tymczasem mitem jest tzw. społeczeństwo obywatelskie, które polega na tworzeniu dobrowolnych stowarzyszeń, zwanych także organizacjami pozarządowymi, mających prowadzić do samoorganizowania się społeczeństwa w celu rozwiązywania pojawiających 
się problemów². Poza tym termin „społeczeństwo obywatelskie” jest kategorią nie tyle analityczną (realnie istniejący obiekt), ile raczej normatywną. Wywodzi się ono z ideologii liberalizmu i zawsze pełniło funkcje ideologiczno-propagandowe. Nieporozumieniem jest bezrefleksyjne przenoszenie pojęć o charakterze normatywno-ideologicznym na obszar analiz empirycznych bez weryfikacji sensowności ich zastosowania.

Z punktu widzenia tradycji politologicznej wielkie znaczenie dla rozwoju badań określanych jako „socjologia polityki” miał przede wszystkim David Easton i jego teoria systemu politycznego. Analiza systemowa na przełomie lat sześćdziesiątych i siedemdziesiątych była w nauce jedną z bardziej wpływowych orientacji teoretycznych i metodologicznych. Wpływ ten był tak duży, że pisano nawet o tzw. rewolucji systemowej traktowanej jako zasadnicza reorientacja myślenia naukowego, która kształtuje nowy paradygmat w nauce. Rewolucja systemowa w nauce o polityce związana była z takimi badaczami, jak David Easton, Karl Deutsch czy też Robert Kaplan. Każdy z tych autorów konstruował pewne modele systemowe, które miały pomóc w rozumieniu specyfiki funkcjonowania systemu politycznego rozumianego jako pewna całość, którą można wyodrębnić w ramach szerszego systemu społecznego (por. Easton, 1953). Podejście systemowe przy budowaniu teorii polityki, najogólniej mówiąc, sprowadzało się do dwóch elementów: 1) różnorodne dziedziny rzeczywistości interpretuje się nie jako luźne zbiory izolowanych elementów, lecz jako wewnętrznie zintegrowane, wyróżniające się od otoczenia i kierujące swoistymi prawidłowościami całości; 2) rozważając poszczególne elementy zjawiska czy procesy, zwraca się uwagę nie tyle na ich cechy absolutne, przysługujące im samym bez względu na kontekst, $\mathrm{w}$ jakim występują, ale raczej na ich cechy relacjonalne, powiązane $\mathrm{z}$ innymi elementami, oraz miejsce i rolę w szerszych całościach (Sztompka, 1975).

Specyfika analizy systemowej wynika z charakteru problemów, jakie porusza, i pytań, jakie stawia. Analiza systemowa to specyficzny sposób poznawania rzeczywistości przez wyodrębnienie całości i jej elementów oraz zbadanie ich oddziaływania wzajemnego, a także zasady badania rzeczywistości przez ujawnianie istoty, rodzajów i właściwości związków wzajemnych między tymi elementami. Główną właściwością badań systemowych jest przyjęcie założenia,

${ }^{2}$ Warto zwrócić uwagę na krytykę tego pojęcia dokonaną przez profesora Bohdana Jałowieckiego, który przy okazji sam autokrytycznie podkreślił, że i jemu zdarzyło się iść za „modą” i mówić o społeczeństwie obywatelskim; por. B. Jałowiecki, Reguły działania w społeczeństwie i w nauce, Warszawa 2002, s. 136-137. 
że system „żyje”, funkcjonuje, a oznaki funkcjonowania prowokują do szukania prawidłowości, kierujących badaniem danego systemu. Z pojęciem i zachowaniem się systemów związane są dwa pojęcia: struktura i środowisko zewnętrzne. Każdy system wyróżnia się specyficznym charakterem współdziałania ze środowiskiem. Środowisko zewnętrzne ma wielkie znaczenie dla funkcjonowania i rozwoju systemu. W teorii systemów przyjmuje się, iż otoczenie systemu jest to określony zbiór elementów, niebędących elementami danego systemu, jednak wykazujących sprzężenia $\mathrm{z}$ nim istotne dla osiągnięcia danego celu. Z punktu widzenia powiązania systemu i jego otoczenia istotne znaczenie mają pojęcia: wejście, wyjście. Wejściem nazywa się zbiór sprzężeń lub zmiennych, za których pośrednictwem wywierany jest wpływ na element lub system elementów. Wyjście zaś to zbiór sprzężeń lub zmiennych, za których pośrednictwem system lub element przejawia swoje zewnętrzne oddziaływania (wpływa na swoje otoczenie) (Habr i Vepřek 1976). Ogólny model systemowy przyjmowany w naukach politycznych zakładał, że system polityczny to: 1) zbiór rozróżnialnych elementów; 2) powiązanych ze sobą różnorodnymi zależnościami, które łącznie tworzą jego strukturę; 3) wyróżniający się od otoczenia za pośrednictwem uchwytnej granicy; 4) ale ulegający oddziaływaniom płynącym z otoczenia poprzez określone wejścia; 5) i oddziaływający na otoczenie poprzez określone wyjścia; 6) przy czym charakter oddziaływań na wyjściach jest wyznaczony przez oddziaływanie na wejściach, zmodyfikowane przez procesy konwersji wewnątrzsystemowej, 7) a charakter oddziaływań na wejściach jest modyfikowany przez procesy konwersji wewnątrzsystemowej (Sztompka, 1975). Warto przy tym pamiętać, że ze względu na charakter swojego sprzężenia z otoczeniem system polityczny jest systemem „otwartym”. Granica między tym, co „społeczne” (społecznym otoczeniem systemu politycznego), a tym, co „polityczne” (systemem politycznym), jest płynna i nieostra. Wytyczenie granicy między systemem a jego otoczeniem oraz określenie tych cech otoczenia, które uważa się za istotne, opisując stan otoczenia (podobnie jak i stan samego systemu), jest uzależnione od badacza określającego konwencję analizy systemu.

Dużą rolę w upowszechnieniu w ramach nauk politycznych analizy systemowej odegrał David Easton, który duże znaczenie przypisywał otoczeniu zewnętrznemu i tzw. wejściom do systemu. Zwolennicy analizy systemowej w ramach nauki o polityce mieli świadomość tego, że system polityczny nie może być sensownie interpretowany jako istniejący w próżni. Musi być zatem rozpatrywany w związku ze swoim otoczeniem fizycznym, biologicznym, społecznym i psychologicznym. Identyfikacja otoczenia jest użyteczna, a nawet konieczna 
w świetle założenia, że system polityczny tworzy system „otwarty”. Pomiędzy systemami politycznymi a otoczeniem złożonym z szerszych społeczeństw zachodzą ciągłe wymiany i przepływy. Nie można zatem wytłumaczyć funkcjonowania oraz dynamiki (równowagi i zmiany) systemów politycznych bez uwzględnienia rozmiarów i rodzajów ich interakcji z otoczeniem społecznym. Dlatego też Easton starał się stworzyć rozbudowaną klasyfikację elementów należących do otoczenia. Wyróżniał on tzw. otoczenie totalne systemu, które dzieli się na dwie zasadnicze kategorie: do pierwszej należą czynniki wewnętrzne, które mieszczą się w ramach tego samego społeczeństwa co rozważany system polityczny. Do drugiej - czynniki leżące poza danym społeczeństwem, w obrębie innych społeczeństw, czy też inaczej - w systemie międzynarodowym. Do składników otoczenia wewnętrznego Easton zaliczył system ekologiczny, system biologiczny, system osobowościowy i system społeczny w sensie wąskim, wyróżniając z kolei w ramach tego ostatniego system kulturowy, strukturę społeczną, system ekonomiczny i system demograficzny (Sztompka, 1975).

W ujęciu nawiązującym do tradycji analizy systemowej Davida Eastona socjologię polityki można postrzegać, z punktu widzenia politologii, jako badanie „społecznego otoczenia systemu”, czy też „społecznego kontekstu polityki”. Jest to chyba najbardziej funkcjonalna z punktu widzenia politologii interpretacja obszaru zainteresowań socjologii polityki, ale trzeba pamiętać, że nie jest to tylko jedna $\mathrm{z}$ możliwych interpretacji. W ramach takiego podejścia przyjmuje się, że socjologia polityki jest tą częścią nauk politycznych, która wychodzi z założenia, iż podsystem polityczny stanowi część większego systemu społecznego, w ramach którego funkcjonuje sfera polityki. Podejmuje się analizy wzajemnych relacji pomiędzy systemem społecznym a jego otoczeniem, analizując fakty i zachowania społeczne zwane zwyczajowo "politycznymi” (Brémond, Couet i Davie, 2006). Takie podejście pozwala sformułować kilka podstawowych założeń związanych z politologicznymi badaniami „społecznego kontekstu”. Po pierwsze przedmiotem badań jest system polityczny i system społeczny. System społeczny jest traktowany jako „otoczenie”/ „środowisko” systemu politycznego. Po drugie podstawowymi pytaniami badawczymi są pytania o to, czy społeczny kontekst determinuje zjawiska polityczne? oraz czy występuje sprzężenie odwrotne i polityka ma znaczenie dla kształtowania się rzeczywistości określanej mianem „społecznej”. Po trzecie w siatce pojęciowej ważną rolę odgrywają takie pojęcia, jak kontekst, struktura społeczna, władza, polityka, kultura narodowa, język, reprezentacje, konwergencja. Po czwarte podstawowym założeniem jest teza, że społeczny kontekst bezpośrednio deter- 
minuje zjawiska polityczne oraz że możemy traktować system polityczny jako „czarną skrzynkę" poprzez analizę powiązań między docierającymi bodźcami a reakcjami. Po piąte w badaniach dotyczących zależności pomiędzy systemem politycznym główną rolę powinny odgrywać teorie strukturalistyczne, teorie kulturowe oraz teorie konwergencji.

Z uwagi na złożoność i wielowymiarowość systemu społecznego podstawowym pytaniem, na które powinien odpowiedzieć sobie badacz, jest pytanie o to, czym jest społeczny kontekst, który chcę analizować. Ogólnie rzecz biorąc kontekst jest traktowany jako presja zewnętrzna wywierana na działanie systemu politycznego. W zależności od autora społeczny kontekst może obejmować takie elementy, jak: a) czynniki koniunkturalne (wojny, kryzysy itp.); b) presję międzynarodową (porozumienia i umowy międzynarodowe, kredyty, konkurencję międzynarodową, cechy środowiska międzynarodowego itp.); c) czynniki socjoekonomiczne (dochód, klasy społeczne, wiek, technologia, demografia, rasa, płeć itp.); d) czynniki kulturowe (wartości, ideologia, oczekiwania społeczne, itp.).

Teorie strukturalistyczne stawiają pytanie, czy struktura społeczna i siła grup społecznych determinuje politykę. Głównymi terminami, które wykorzystuje się w tego rodzaju badaniach, są struktura, klasa, podziały socjopolityczne, tożsamość. Podstawowe tezy przyjmują, że nierówna dystrybucja dóbr społecznych pomiędzy grupami determinuje ich możliwości wpływania na procesy polityczne i wymuszanie polityki preferującej daną grupę. Kiedy w systemie politycznym dominują grupy uprzywilejowane, dominuje polityka preferująca elity społeczne oraz rosną nierówności społeczne. Grupy nieuprzywilejowane mogą podjąć próbę zmiany sytemu (rewolucja, przewrót reformy), jeśli uda im się wykształcić silną polityczną tożsamość oraz pojawi się odpowiedni przywódca. Kiedy w społeczeństwie nie ma większych nierówności społecznych oraz funkcjonuje system demokratyczny, prowadzona przez instytucje polityczne polityka zależy od równowagi sił pomiędzy poszczególnymi grupami nacisku³ $\mathrm{W}$ teoriach kulturowych podstawowym pytaniem badawczym jest pytanie o to, czy kultura narodowa determinuje specyficzny charakter polityki w danym państwie/ społeczeństwie. Podstawowym pojęciem jest pojęcie kultury politycznej. Tezy podejścia kulturowego zakładają, że polityka może być rozumiana tylko w kontekście historycznie ukształtowanej kultury narodowej, gdyż kultura wpływa na charakter i funkcjonowanie instytucji politycznych. Sposób działania instytucji

\footnotetext{
3 Typowym i klasycznym przykładem teorii strukturalistycznych jest marksistowska teoria klas.
} 
politycznych jest odzwierciedleniem specyficznej dla danej grupy kultury ${ }^{4}$. Teorie konwergencji stawiają pytanie, czy poszczególne państwa naśladują dominujące globalnie wzory polityki. Czy polityka oraz rozwiązania instytucjonalne upodabniają się w skali całego globu? Czy przenikanie wzorów z krajów wyżej rozwiniętych powoduje upodobnienie się systemów politycznych? Siatka pojęciowa jest budowana wokół takich terminów, jak globalizacja, konwergencja, modernizacja. Teza, którą wysuwają zwolennicy teorii konwergencji, zakłada, że presja zewnętrzna i globalne przenikanie wzorców ekonomiczno-politycznych powodują upowszechnienie się praktyk politycznych pochodzących z krajów dominujących. Postępująca globalizacja świata wymusza konwergencję systemów politycznych. W ramach tych teorii głoszony jest pogląd o nieuchronnym kształtowaniu się zbieżnych zasad organizacji życia polityczno-gospodarczego pod wpływem globalizacji oraz postępu naukowo-technicznego.

Socjologia polityki jest szerokim i wieloaspektowym „polem badawczym”. Trudność z jednoznacznym zdefiniowaniem jej specyfiki wynika z faktu, iż wywodzi się ona $\mathrm{z}$ różnych tradycji badawczych i różnie można interpretować jej przedmiot badań. Trudno jest odmówić znaczenia, jakie ma analiza „społecznego kontekstu funkcjonowania systemu politycznego" dla budowania wiedzy o polityce. Jak pisał wybitny polski socjolog profesor Julian Hochfeld analiza jakiegokolwiek zjawiska/fenomenu politycznego (np. systemu parlamentarnego) musi wychodzić daleko poza badanie norm prawnych, a nawet praktyk i zwyczajów regulujących działalność tego systemu. Analiza taka powinna zaczynać się od lokalizacji zjawisk politycznych jako elementu całego społeczno-historycznego porządku. Porządek ten ma swą historię i koneksje i może być w istocie zrozumiany tylko jako element konkretnej społeczno-historycznej struktury, w związku z tą strukturą i jej poszczególnymi elementami (Hochfeld, 1982, s. 287-288). Socjologię polityki i jej rolę w ramach budowy wiedzy o polityce można postrzegać jako swoistego rodzaju „analizę kontekstową”, bez której nie można w pełni zrozumieć prawidłowości funkcjonowania sfery „polityczności”. Kontekst, „otoczenie systemu politycznego”, może mieć różny charakter: biologiczny, fizyczny (geograficzny), psychologiczny, czy też wreszcie społeczny. Ten ostatni jest przedmiotem analiz w ramach podejścia badawczego określanego mianem socjologii polityki, którego celem jest: 1) lokalizacja rozpatrywanych zjawisk/fenomenów politycznych jako elementów pewnych konkretnych,

4 Typowym i klasycznym przykładem teorii kulturowych są badania Gabriela Almonda i jego współpracowników nad kulturą polityczną. 
historycznie danych struktur; 2) charakteryzowanie tych zjawisk ze względu na ich funkcjonalne związki z innymi elementami owych struktur; 3) szukanie wpływu, jaki wywierają na zjawiska politycznie różnorodne, działające w otoczeniu społecznym czynniki (Hochfeld, 1982, s. 286-287). Jest to pewien sposób rozumienia relacji między polityką a społeczeństwem, stanowiący raczej pewne metodologiczne podejście, a nie samodzielny obszar dociekań badawczych.

W socjologicznej interpretacji socjologia polityki będzie subdyscypliną socjologii koncentrującą się na zjawiskach władzy. Dla politologii natomiast jest to nie tyle osobna „subdyscyplina” politologii, ile raczej pewne podejście metodologiczne pozwalające na analizę zjawisk politycznych w ich wielowymiarowych relacjach $\mathrm{z}$ otoczeniem społecznym. Socjologia polityki w systemie wiedzy politologicznej byłaby zatem raczej specyficznym podejściem do analizy obiektów politycznych. Wypracowane w ramach takiego podejścia twierdzenia odnośnie istoty sfery polityki stanowią ważny element teoretycznej wiedzy politologicznej. Trudno sobie wyobrazić, aby można było prowadzić jakiekolwiek analizy zjawisk politycznych bez uwzględniania kontekstu, w jakim one zachodzą. Ale trzeba pamiętać, iż uwzględnienie kontekstu biologicznego zachowań politycznych nie powoduje, że politologia jest tożsama z biologią, uwzględnienie kontekstu przestrzennego nie oznacza, że politologia jest tożsama z geografią, a uwzględnienie kontekstu społecznego nie oznacza, że politologia jest tożsama $\mathrm{z}$ socjologią. Problem związany z traktowaniem socjologii polityki jako obszaru analiz dotyczącego „społecznego otoczenia polityki” jest taki, że analizę społecznego kontekstu zjawisk politycznych można określić mianem „socjologii polityki", ale w rzeczywistości jest to nie tyle osobny obszar badawczy, ile raczej specyficzne podejście do badania sfery polityki. Warto przy tym podkreślić znaczenie takiego podejścia, gdyż różnorodne fenomeny polityczne, np. partie polityczne, elity polityczne, zachowania wyborcze, politykę społeczną, sposoby legitymizacji władzy, sposoby dystrybucji władzy itp., można zrozumieć tylko poprzez umiejscowienie ich w odpowiednim kontekście społecznym (kulturowym) i historycznym. Dla budowy wiedzy o polityce, czy też w systemie wiedzy politologicznej, socjologia polityki, niezależnie od tego, czy będziemy ją traktować jako „socjologię władzy”, czy też „badanie społecznych podstaw polityki”, ma doniosłe znaczenie. Nie da się bowiem zbudować żadnej rzetelnej analizy sfery polityczności ani bez socjologicznej wiedzy o specyfice fenomenu władzy, ani bez analizy kontekstu społecznego, czyli otoczenia systemu politycznego. Trzeba także pamiętać, że wszelkie pojęcia, modele i teorie są jedynie narzędziami analitycznymi. Wspierają rozwój procesu rozumienia rzeczywistości, ale zawsze 
będą bardziej ogólne i spójne niż złożona rzeczywistość, którą starają się opisać. Podział na poszczególne pola badawcze i dyscypliny akademickie był zawsze sztuczny czy też - inaczej mówiąc - analityczny, a nie rzeczywisty, tj. mający odbicie w badanej rzeczywistości społecznej. Rozróżnienia na poszczególne dyscypliny mają zatem charakter nie ontologiczny, ale analityczny. Rozróżnienie pomiędzy poszczególnymi sferami życia społecznego, które występuje w ramach nauk społecznych, jest ważne i użyteczne, gdyż kieruje naszą uwagę na różne aspekty i wymiary zintegrowanego życia społecznego. Niebezpieczeństwo tkwi w tym, że dość często można dostrzec proces „ontologizacji”, a tym samym reifikowania jedynie analitycznego rozróżnienia. Efektem tego może być wprowadzenie zbyt sztywnych granic pomiędzy politologią a pokrewnymi jej dziedzinami nauk społecznych.

\section{BIBLIOGRAFIA:}

Bendix, R., Lipset, S.M., (1957). Political sociology. An essay with special reference to the development of research in the United State of America and Western Europe. Current sociology, vol. 6(2), s.79-105.

Bottomore, T. (1993). Political sociology. Londyn: Pluto Press.

Brémond, A., Couet, J-F., Davie, A. (2006). Kompendium wiedzy o socjologii. Warszawa: PWN.

Easton, D. (1953). The political system. An Inquiry into the state of political science, Nowy Jork: Knopf.

Faulks, K. (2000). Political sociology. Nowy Jork: NYU Press.

Giddens, A. (2001). Nowe zasady metody socjologicznej. Kraków: Zakład Wydawniczy NOMOS.

Habr, J., Vepřek, J. (1976). Systemowa analiza i synteza: nowoczesne podejście do zarzqdzania i podejmowania decyzji. Warszawa: Państwowe Wydawnictwo Ekonomiczne.

Hochfeld, J. (1982). Marksizm, socjologia, socjalizm. Wybór pism. Warszawa: PWN.

Kidd, W., Legge, K., Harari, P., (2010). Power \& politics, Basingstoke: Palgrave Macmillan. Lecomte, J-Ph. (2005). Sociologie politique. Paryż: Gualino Editeur.

Lipset, S. (1995). Homo politicus. Spoleczne podstawy polityki. Warszawa: PWN.

Modrzejewski, A. (2011). Metodologiczne i filozoficzne podstawy politologii. Zarys wykładu. Gdańsk-Elbląg: Oficyna „OKO”.

Nash, K. (2008). Political sociology. Globalization, politics and power. Malden-Oxford: Willey-Blackwell.

Neuman, W.L. (2005). Power, state and society. An introduction to political sociology, Nowy Jork: McGrawHill.

Olsen, M.E. (1981). Comparative political sociology. International Journal of Comparative Sociology 1981, vol. XXII (1-2), 40-61. 
Orum, A. (1983). Introduction to political sociology: the political anatomy of the body politic, New Jersey: Prentice-Hall.

Potulski, J. (2011). Wprowadzenie do socjologii stosunków politycznych. Gdańsk: Wydawnictwo Uniwersytetu Gdańskiego.

Sartori, G. (1969). From sociology of politics to political sociology. Government and Oppositions 1969, $n$ r 4, 195-214.

Skarzyński, R. (2012). Podstawowy dylemat politologii: dyscyplina nauki czy potoczna wiedza o społeczeństwie? Białystok: Wydawnictwo Temida 2.

Sztompka, P. (1975). Analiza systemowa w naukach politycznych. W: K. Opałek (red.), Metodologiczne i teoretyczne problemy nauk politycznych, (s.77-108). Warszawa: PWN.

Sztompka, P. (2002). Socjologia. Kraków, Wydawnictwo Znak.

Taylor, G. (2010). The new political sociology, Basingstoke: Palgrave Macmillan.

Wallerstein, I. (2004). Koniec świata jaki znamy. Warszawa: Wydawnictwo Naukowe SCHOLAR.

Weber, M. (2002). Gospodarka i społeczeństwo. Warszawa: PWN.

Weber, M. (2004). Polityka jako zawód i powołanie. W: M. Weber, Racjonalność, władza, odczarowanie, Poznań: Wydawnictwo Poznańskie.

Wiatr, J. (1999). Socjologia polityki. Warszawa: Wydawnictwo Naukowe SCHOLAR. 